\title{
Doing things with numbers: Chinese approaches to the Anthropocene
}

\author{
Susanne Weigelin-Schwiedrzik ${ }^{1}$ (D)
}

Received: 28 October 2017 / Revised: 1 February 2018/Accepted: 22 February 2018/

Published online: 8 March 2018

(C) The Author(s) 2018. This article is an open access publication

\begin{abstract}
This paper looks at Chinese approaches to the Anthropocene by way of discussing the idea of Green GDP and recent attempts to implement this new way of calculating the GDP in the PRC. It argues that the Green GDP project which is outside China often regarded as a piece meal solution might indeed be of major importance for inducing a shift away from GDP-ism (唯 GDP-主义) as the dominant development model for China. The paper contributes to the on-going discussion on the Anthropocene (Bostic and Howey 2017; Chin et al. 2016; Jahn et al. 2015) by including a reflection on our hopes and expectations vis à vis China's potential contribution to preserving the planet and by analyzing the Green GDP project and its implications in a more general sense. While Green GDP calculations have the advantage of making costs and gains of economic growth transparent, the big data which form the basis of Green GDP calculations imply that everything we do has to be quantified and controlled. Introducing Green GDP calculations is a continuation of GDP-ism with other means and no break away from the kind of mindset which stands at the cradle of the Anthropocene. But in comparison to more radical policies, it has the potential to bring about change for China and the world at large without provoking major societal conflicts.
\end{abstract}

Keywords Anthropocene · China · Green GDP

\section{China as a threat and a thrill}

In times of crisis, Europeans tend to perceive China as either a threat or an alternative solution to fundamental problems. After the "yellow peril" had taken over the news headlines at the end of the 19th century, it did not take long for

Susanne Weigelin-Schwiedrzik

susanne.weigelin-schwiedrzik@univie.ac.at

1 University of Vienna, Vienna, Austria 
European intellectuals to discover China's traditions as a remedy to Europe's crisis of modernity in the aftermath of World War I. While the fear of China has never left us ever since, the hope for China generating an alternative modernity is also still with us. It is this hope which is at the roots of Europeans dreaming of a Chinese past rather than looking at the Chinese present. However our interest in China's past is more an interest in its philosophies than its history. And among the philosophies the search for alternative solutions goes more into the direction of Daoism than of Confucianism. Without going too deep into the matter, intellectuals in Europe regard Confucianism as an anthropocentric theory of state, while they find an interest in Daoism as an anthropocosmic philosophy dealing with men's relationship to nature (Snyder 2006). ${ }^{1}$

In the field of Chinese Studies, growing awareness of the environmental crisis we have been producing led to scholars like Alan Watts looking into Eastern traditions in his book "Nature, Man and Woman" published in 1958 (Watts 1958) and Lynn White suggesting in 1967 "that Eastern religious traditions might offer antidotes to the environmentally destructive trajectories of Judaism and Christianity" (Snyder 2006, p. 100). In addition to these comparatively early interventions from the field of East Asian Studies, the American Academy of Religion started a subgroup of Religion and Ecology as early as 1991 which organized several conferences and published a book series on World Religions and Ecology from 1997 to 2004 (Snyder 2006, p. 101). At about the same time, a report was made to the Academic Advisory Board of the then Federal Government of West Germany stressing the necessity to look at the attitude of different religions towards ecology and dealing explicitly with both Confucianism and Daoism. This report comes to the conclusion that there is no sign that philosophies such as Confucianism or Daoism have been translated into ethical behavior vis à vis nature. Daoism, according to this report, is too radical to have an impact on everyday practices; and the idea of Confucianism that men is part of nature has so far not resulted in defining any concrete ideas of how to safeguard the environment (Pye et al. 1997). Despite these notes of caution, Snyder in his recent review article on "Chinese Traditions and Ecology" comes to the overall assessment that "Western scholars are increasingly turning to the religious traditions of the world in their search for ways of mitigating the ever-escalating global ecological crisis. For many, turning to Daoism, or any other unfamiliar tradition for that matter, offers fresh perspectives from which to view the world and the human place in it." (Snyder 2006, p. 101).

China plays a major role in this search for solutions, as we all seem to know that a solution for China would be a solution with enormous impact on the world at large; and a Chinese solution for China would be by far the best solution. However, contributions from the field of Chinese Studies such as publications by Mary Evelyn Tucker and others have so far not found an answer to a question raised by $\mathrm{Yi}-\mathrm{Fu}$ Tuan already back in 1968 (Tuan 1968). While Tuan underlines that Chinese traditions provide for an abundance of "environmentally friendly beliefs", he notes

\footnotetext{
1 This paper is based on research funded by the Jubilee Fonds of the Austrian National Bank (20092010). I would like to thank Julia Marinaccio who was on the team of that project at the time and contributed to the sub-chapter "A short history of Green GDP in China" with her research. Additionally, I would like to thank Josef Baum for making us interested in this issue and leading us through the project.
} 
that "actual practices of the Chinese have hardly lived up to the ideal expressed in their traditions" (Snyder 2006, p. 104). This is a puzzle which the history of China confronts us with, and it is a puzzle which stays unresolved up until today. The puzzle reminds us of the fact, that our search from outside China is obviously based on an understanding of Chinese traditions which differs fundamentally from the indigenous interpretations. We are looking for a change of mindset to be induced by Confucianism or Daoism, however, we have no proof in history that the mind was ever set by either Daoism or Confucianism in a way so that to produce the kind of practical results we are hoping for today.

\section{Chinese approaches to the Anthropocene}

In China, the discussion on the Anthropocene is traceable back to when it started internationally in the early 2000s with Nobel Prize laureate Paul J. Crutzen publishing his notable article in Nature. In this article, Crutzen assigned "the term 'Anthropocene' to the present, in many ways human-dominated, geological epoch, supplementing the Holocene-the warm period of the past 10-12 millennia." (Crutzen 2002, p. 23). The Chinese term for the Anthropocene appears only shortly afterwards and can be found in papers written by the well-known geologist Liu Dongsheng (刘东生) (Liu 2004).

In the PRC, the debate on the Anthropocene is first and foremost a debate among geologists. Their discussions focus on the question what the idea of the Anthropocene might mean for the development of their discipline from geology to earth science and to which degree the profession of earth scientists needs to redefine its identity and its way of conducting research. A national 15-yeardevelopment plan of the earth sciences for the years 2005-2020 includes an explanation of the term "anthropocene" (人类世). It argues that the complexity of dealing with issues of the Anthropocene is unprecedented and therefore calls for new research methods to cope with new challenges such as the difficulty of interdisciplinary research, the difficulty of reproducing research results and the difficulty of having to deal with continuous interventions of men in nature with uncertain effects. Whoever works on issues of the Anthropocene is confronted with an object of inquiry in constant flux (Development Plan 2005). Traditionally, a geological epoch was defined ex post, now earth scientists are confronted with a geological epoch which is still in the making (Gebhardt 2016).

The discussion on the question when the Anthropocene started reaches from the field of earth science into the field of history. In contrast to Crutzen who argues that the Anthropocene started during the 18th century (Crutzen 2002, p. 23), Liu Dongsheng holds that mankind has been using, influencing and exploiting nature for its own purposes for thousands of years which is why he defines the Anthropocene as reaching back approximately 10,000 years (Liu 2004, p. 369). This kind of definition is also propelled by a group of historians who argue that there are many written documents in Chinese history which attest to the fact that men started early on to destroy nature in order to find better conditions for survival. Others explain that the situation we are confronted with now has been building up momentum since 
the end of World War II and the dropping of nuclear bombs over Hiroshima and Nagasaki. Yet another group of discussants argues that the beginning of the Anthropocene should be set for the beginning of industrialization (Liu et al. 2017). The above mentioned paper by the society of Earth Sciences takes a comparatively radical position by going back to the 1980s as the beginning of the Anthropocene (Development Plan 2005, p. 29).

The differences in periodization represent in fact fundamental differences of world view. While discussants inside and outside China (Gebhardt 2016) who stress that mankind is confronted with a radically new situation in the Anthropocene tend to go for a shorter period reaching back at most to the beginning of industrialization, others who look at the Anthropocene in terms of 10,000 years like Liu Dongsheng imply in what they say that industrialization is only a gradual change in men's use of nature. If the last argument is the basis of further deliberations it leads to a less radical view on what has to be done to deal with the implications of the Anthropocene for today's human behavior. In contrast, the assumption that we are now dealing with a comparatively young and totally novel phenomenon leads to more radical self-incriminations and more uncertainty in dealing with possible remedies. This way of dealing with the Anthropocene appeals to men's ability to design a radically new future; in contrast, the less radical view on the Anthropocene makes it possible to look at the past in order to understand how we can anticipate the future and how actions in the past did or did not contribute to repair the damage.

This uncertainty about the novelty of problems we are confronted with in the Anthropocene is also reflected in the discussions we find among yet another group of people concerned with the Anthropocene. They are to be found among artists and writers. As we know from Andrea Riemenschnitter's (Riemenschnitter forthcoming) research, authors like Ge Fei in his 2004 trilogy “Trilogy on Jiangnan” (江南三 部曲) seem to go back to the reservoir of traditional Chinese literature in order to develop a utopia for the Anthropocene (Ge Fei 2012). They seem to rely on the intuition inspired by the arts to anticipate what it means to live in a world which is destroying itself. However, there are also attempts to use the more recent past as a reference for designing a possible future for life in the Anthropocene. The 2016 novel “Anhropocene" (人类世) written by the Shandong author Zhao Defa (赵德 发) is more of this latter kind (Zhao 2016). This novel uses literary techniques from the repertoire of realism. It discusses life in the Anthropocene by writing the story of the rise and fall of a Chinese businessman who starts as a waste picker, develops into a mega-rich and finally ends in total catastrophe. It juxtaposes this story with the attempts of a scientist who is enthusiastically looking for a solution to the problems of the Anthropocene, but caught in despair and depression. The author is known for his "anthropological" interest in religion and, indeed, also discusses the possibility of religions helping to find a solution for the problematique of the Anthropocene. But he comes to the conclusion that religions do not provide for a solution (Fenghuang 2016). The reader learns to accept and understand the motives of the businessman who in his moving life story combines all the struggles, bitterness (苦) of the past and hopes for the future which stand for China and its history since the middle of the 19th century. At the same time, he or she empathizes with the scientist and his students and their environmentalist enthusiasm. But the 
coexistence of the two stories is not the solution; it is the problem the novel deals with: the catastrophe is real, but the way out of the catastrophe is not real. The world of the businessman and the world of the scientist are two co-existing worlds in which none provides for the answers. Insights from the sciences and environmentalist enthusiasm are not strong enough to convince those longing for wealth and power to change their lifestyle before the catastrophe arrives. Thus the novel discusses Chinese society as fundamentally split with regard to different ways of coping with, reacting against or else overcoming the on-going environmental crisis.

The on-going discussion on the Anthropocene in China, indeed, seems to be developing in two worlds which are mostly unrelated, but at the same time intersect with each other. Not only do earth scientists identify questions which the artists do not find an interest in; the epistemological approach the discussants prefer in dealing with the Anthropocene is also quite different. In this context, the realist writer Zhao Defa is closer to the earth scientists and fundamentally different from Ge Fei. However, by looking at repertoires from the past, Ge Fei uses a similar approach as those geologists and historians who look at history in order to understand the present and anticipate the future. All participants of the discussion share, however, the same fate: Their deliberations have not yet attracted media attention and therefore have not yet been able to exert a noticeable influence on a change of mindset which they all seem to hope for.

\section{Green GDP: a practical rather than a philosophical solution?}

With no philosophical and fundamental solutions in sight and the change of mindset still nearly undetectable, practical and incremental solutions might need to be looked at. ${ }^{2}$ In the context of the history of ideas in China, Confucian scholars of Ming (1368-1644) and Qing (1644-1912) times were divided on the issue whether reflections on a crisis should be more abstract or more concrete. Qing scholars criticized the philosophers from the neo-Confucian Song school for having engaged in "empty talk" (空谈) rather than contributed to finding concrete solutions when the Ming was confronted with its enemies from among the Babarians which eventually took over China in 1644. However, during the latter half of the 19th century, when the Qing Dynasty was trying to prevent its own collapse, all the concrete and practical reform measures which the elite initiated were unable to impede the regime change of 1911 from happening. After 30 years of visionary plans for China producing more unintended than intended results under the leadership of Mao Zedong, since 1978, the Chinese elite has embarked again on a "pragmatic" course of solving China's problems. Today, Chinese society in its majority seems to be dubious about fundamental and big concepts and have more confidence in "practical" solutions to problems.

The idea of Green GDP accounting is such a "practical" idea. Internationally, Green GDP is defined "to designate a 'corrected' GDP number, or sometimes a

\footnotetext{
${ }^{2}$ In China, the discussion on Green GDP is not related to the discussion on the Anthropocene. It is my intention to show that from an outsider's point of view, the Green GDP solution might be more of a contribution to dealing with the environmental crisis than waiting for a fundamental change of mindset.
} 
'corrected' GDP growth rate, where the correction seeks to take into account the depletion of non-renewable resources, as well as various damages to the environment due to pollution to air, water and soil, and also sometimes loss of ecosystem services as a consequence of pollution from economic activities. To find the true net benefits of economic activities, these activities should obviously be corrected for all costs that are associated with the economic activities. Hence, these costs should be deducted from the traditional GDP to obtain a greener GDP." (Alfsen et al. 2006, p. 9).

The idea of Green GDP has been under discussion since the late 1980s with Norway acting as one of the forerunners. In 1993, the UN published a first "Handbook on National Accounting: Integrated Environmental and Economic Accounting" which served as a starting point for the worldwide discussion. In 1994, the London Group on Environmental Accounting ${ }^{3}$ launched a project to develop a set of indicators and calculation procedures which produced yet another widely acclaimed handbook in 2003. In 2001, the Nairobi Group ${ }^{4}$ published under the responsibility of UNSD and UNEP an updated handbook under the title of "Handbook of National Accounting: Integrated Environmental and Economic Accounting-An Operational Manual" which was translated into Chinese (Alfsen et al. 2006, p. 19). Alas, a 2006 paper by Knut H. Alfsen et al. comes to the conclusion: "Nevertheless, more than thirty years with natural resource accounting and experiments with green accounting and indicators like green GDP, we still do not see any form of international consensus." (Alfsen et al. 2006, p. 7, for more information on the international development see ibid., 19-31).

This might be the reason why in most countries of the world, the discussion on Green GDP has been of a purely academic nature. The only exception from this rule is the PRC as both government and academia have shown a keen interest in this calculation procedure. Environmental activists as well as government officials hope that Green GDP provides a perspective that can help improve environmental protection and rational resource utilization (Ni 2004). The enthusiasm for Green GDP has been a reaction to the wide-spread GDP-ism and is part and parcel of the attempt to depart from a development model exclusively focused on economic growth. However, as the PRC's development model and its obvious successes have been well acclaimed internationally and have provided the basis of the legitimacy of one-party-rule in China, it is not easy to replace it even if the aggravating environmental situation in the PRC is pushing a change of development policy to the very top of the agenda. The history of Green GDP calculation in China therefore is a history of enthusiasm and disappointment, of success and failure, of stop and go.

\footnotetext{
3 "The London Group on Environmental Accounting is a city group created in 1993 to allow practitioners to share their experience of developing and implementing environmental accounts linked to the System of National Accounts. It convened its first meeting in March 1994 in London, England. The name derives from the city of its first meeting." (https://unstats.un.org/unsd/envaccounting/londongroup/).

4 This is a group of experts from national and international agencies and non-governmental organizations established in 1995.
} 


\section{A short history of Green GDP in China}

In the PRC, research on measuring the costs of ecological and environmental factors started already in the late 1970s. After the mid-1980s, more prominent results in methodological and theoretical research were achieved and the number of publications increased. They covered all fields for which up until today no consensus has been reached, especially the problem of environmental valuation, environmental pollution damage measurement, and environmental economic models (Wang et al. 2004, p. 1). However, contributions were individual and it was not until the 1990s that scientific institutions engaged in the research on environmental impact and associated costs. In 1996, the Division of ResourcesEnvironmental Accounting was established by National Bureau of Statistics (NBS) in the Department of National Accounting 国民经济核算司 and started collaboration with Statistics Norway in 1998 in developing an accountant procedure focused on energy. In 1998, local pilots were launched involving forest development both in Heilongjiang and Hainan. In 2004, NBS started cooperating with Canadian International Development Aid (CIDA) focusing on methodological and theoretical issues (Alfsen et al. 2006, pp. 32-34). This shows that the NBS had been active in building capacity in the field of Green GDP accounting early on.

However, other institutions also started getting involved. In 1998, SEPA (State Environmental Protection Agency) and the World Bank jointly conducted a project entitled Calculation of Genuine Saving in which Yantai City 煙台市 of Shandong Province 山东 and Sanming City 三明市 of Fujian Province 福建 were selected to act as pilot locations (Yu et al. 2006, p. 4). Later on, SEPA and the World Bank began to conduct Research on Valuation Approaches for Chinese Environmental Pollution Costs (Yu et al. 2006, p. 4). In 2003, SEPA approached the World Bank to develop an estimate of its air and water pollution costs, including the human health impact. According to the World Bank "this was triggered by a growing concern on China's part that its rapid economic growth was carrying a large environmental and human health cost" (World Bank 2007). China set up an international joint research team to develop an accounting model based on research that had been conducted by SEPA and the Ministries of Health 国卫生部 and Water Resources 国水利部. It was the first research project of this kind in a developing country. The report was published in 2007 (World Bank 2007). With SEPA, a second state agency entered the field of research on Green GDP, gaining international support from other institutions than NBS and building up leverage in Green GDP related debates.

In 2004, the idea of Green GDP reached a first zenith with the then President of the PRC, Hu Jintao 胡金涛, using the terminology “Green GDP" for the first time officially in a speech given on March 10, 2004 (Hu 2005). Consequently, the above mentioned institutions announced together with a number of research institutes that they would hope for a calculating procedure to be established within the next 3 to 5 years. To reach this aim, NBS and SEPA would join forces. This announcement was a major breakthrough, especially for SEPA: "With the overall environmental situation in China aggravating, this most responsible government institution came under ever growing pressure. As a 'weak institution' with only 220 employees 
including the door guards, it needed to use more political instruments to build up its capacity in coping with environmental problems. That is ...how Green GDP became a natural 'political demand' for SEPA." (Wang 2007).

In a newspaper article published in China Daily in December 2004, Xu Xianchun 许宪春, the director-general of the Department of National Accounting of NBS, formally announced the project of combining forces with SEPA and a number of research institutes to calculate China's national Green GDP. The calculation methods to be adopted and agreed upon were those the United Nations had stipulated in 1993 as the so called "Environmental Economic Accounting" (SEEA) scheme. Calculations were to be focused on land, forestry, mineral, and water resources, as well as on designing a model of energy resource accounting. The announcement further explained that the calculation systems would undergo three steps: (1) Assessment of the quantity of natural resources consumed by economic activities; (2) assessment of the environmental loss caused by economic development; and (3) assessment of the quantity of lost resources and environmental damage (China Daily 2004).

In September 2006, the national Green GDP for 2004 was published. SEPA announced that pollution had caused a loss of 511.8 billion Yuan (U.S. \$64.4 billion). This corresponds to $3.05 \%$ of the GDP. However, the data were immediately disputed both within and outside of China as the September announcement contradicted an estimate by Zhu Guangyao 朱光耀, Director of the International Department of the Ministry of Finance, given the year before: This estimate had stated that pollution costs would exceed U.S. \$200 billion, or 10 per cent of the GDP (Lelyveld 2006).

The data for the year 2005 were withheld and an "indefinite postponement" (Qiu 2007, p. 518) of their publication was announced in July 2007. At a press conference, Xie Fuzhan 谢伏瞻, the Director of NBS, openly questioned the feasibility and methodology of the report for the year 2004. Also, the fact that no international consensus on a valid standard for Green GDP accounting had so far been achieved was held against the publication of Green GDP data (China Online 2007). Nevertheless, Wang Jinnan 王金南 of the Chinese Academy of Environmental Planning (CAEP, 环境保护部环境规划院) spoke in defence of the project and explained that the report was not published due to disagreements between SEPA and NBS. This dispute had never been a secret: since the launch of the project in 2004, the two agencies had been arguing over the new accounting scheme (Qiu 2007, p. 518). This is how the project of calculating Green GDP came to a sudden halt. The NBS which had started calculating environmental depletion early on and which monopolizes all data collection in the PRC boasted of its expertise in data collection and statistical processing while SEPA wanted to gain momentum by publishing Green GDP data as early as possible. The fact that technical problems were said to be the reason for putting the project on halt seems to imply that NBS had won the battle between the technicality and the politics of Green GDP.

In addition, there is reason to believe, that the overall political situation did not allow for Green GDP calculations to be publicly discussed. At the time, the government of the PRC still heavily relied on high growth rates as a basis of its legitimacy. No matter how a Green GDP would be calculated, it would certainly 
have reduced the yearly propagated GDP growth rate by several percentage points and would have damaged the image of an ever growing economy in the PRC. Environmental problems were still not regarded as a potential reason for widespread societal unrest. Therefore the costs of Green GDP accounting were estimated as exceeding the potential gains. The pragmatism of power politics was stronger than concerns for the environment, and hopes for short term profits were stronger than fears of long-term irrepairable damage. Although the idea of Green GDP accounting was very much in tune with the overall orientation on "scientific development" (科 学发展观) propagated by the Hu Jintao/Wen Jiabao 温家宝 leadership of the CCP it was at that time unable to generate the kind of turn-around in developmental policies which would have made Green GDP accounting possible.

Despite its defeat, the Green GDP project managed to survive. In this context, two events had a major impact on the revival of interest in Green GDP accounting. The 2008 Beijing Olympics put both central and municipal governments under enormous pressure to enhance the quality of the environment in Beijing and beyond. The same is true for the World Exhibition in Shanghai in 2010. Shanghai had to develop a "green" concept for the World Exhibition and had to present a vision for a "green" Shanghai before the final decision on its bid was taken. Thus two megacities in China had learned to be rich and "green" which helped to ease the perceived tension between sustainable "green" growth and fast "black" growth (Sze 2015).

The discussion on the scientific development view, as agreed upon by the 16th Party Congress in 2002, finally started to have some influence on the attitude of local governments towards the Green GDP accounting system. While a certain reluctance on the side of local governments could be observed when SEPA and NBS announced their joint project in 2004, press articles in 2009 and 2010 attest to a growing interest in a green economy and in Green GDP on the side of some provinces. This is especially true for those provinces which are lagging behind in terms of industrialization and economic growth. According to an article by Chang Jie 常婕, Hubei 湖北 launched a development project on "creating a province of green economic strength" (Chang 2009, p. 78) in order to foster social and sustainable economic development throughout the province. In this context, Green GDP could serve as a measurement of Hubei's progress in pursuing its plan for a strong green economy whereas sticking to the traditional method of GDP accounting would make Hubei with its "green" plans look deficient. While some regions in Hubei province relied on import-export-industries, others could profit from a Green GDP accounting system by having their focus on preserving the environment valued. These efforts on the part of the less industrialized areas of Hubei would by means of Green GDP accounting contribute to an overall positive image and reputation of the province. From an academic point of view, initiatives like those taken by the Hubei provincial government could provide both experience and data for an appropriate Green GDP accounting model which would eventually be implemented throughout the whole country (Chang 2009, p. 78). However, as Chang Jie suggests, these plans cannot become true without the support of the population, of local governments and enterprises. For that reason Chang suggests to 
form a special agency created to lead, manage, and execute the project (Chang 2009, p. 79).

Another example of how less industrialized regions responded positively to and advocated the continued development and use of Green GDP is Anhui Province 安 徽. In early 2009, the government decided to raise the idea of Green GDP to the level of a guiding political principle and to regard it as the most important criterion for assessing the performance of cadres, governments, and agencies. The provincial government intended to make Huangshan 黄山-the capital of Anhui province-a city of new ideas for scientific development ( $\mathrm{Wu} 2009$ ).

In an article on Shennongjia 神农架, also in Hubei Province, Fu Keyou 付克友 explained that due to the region's vast forests it accounts for an average of three million tons of oxygen production per year. In Green GDP accounting, it ranked among the highest and could be proud of being one of the greenest areas in China (Fu 2009). However, despite a wealth of natural resources, Shennongjia has an extremely low growth rate, placing it amongst the poorest regions in China in economic terms. For its contribution to safeguarding the natural environment, the local government received a subsidy of merely 500,000 RMB. The government intended to request to raise the subsidy to an adequate level. Fu argued that there were other regions like Shennongjia which were willing to sacrifice economic growth for a good ecological environment. He suggested the creation of a market for pollution certificates. Regions such as Shennongjia, which contribute with their natural environment to the overall quality of life in the PRC, should be compensated on the basis of the Green GDP accounting system. Industrialized regions with a negative effect on the environment should pay for the pollution they are responsible for instead. In addition, industrialized regions could buy pollution rights from poorly industrialized green areas and thus support their efforts in terms of preserving the green environment and raising the standard of living. Fu (2009) concluded that Green GDP, combined with a carbon emission market, would provide an opportunity for the PRC to overcome regional disparities without forcing the industrialization strategy on all parts of China.

The idea of establishing a carbon emission market supported by Green GDP accounting was also shared by administrators from Jiangxi Province 江西. Jiangxi is known as a province where economic activities with low $\mathrm{CO} 2$ emissions are said to be a great success in both ecological and economic terms. In this context, Gutan 谷 滩, Gaoxin 高新, and Wanli 湾里were selected to act as low carbon demonstration zones (低碳经济的示范区). Liu Jiang 刘江, head of the Nanchang Development and Reform Committee, argued that Nanchang's ecological conditions and low CO2 emissions would ultimately result in the region's economic superiority. Low CO2 emissions were the result of low consumption, low pollution, and low emissions. Despite some critical voices which suggested that a market for pollution rights would lead to fierce competition between various cities, with low emission economies hindering or at least delaying the development of Jiangxi province, Liu Jiang was convinced that Nanchang had given evidence of the opposite. Interestingly, Zhou Guanze 周关则 of the CCP Propaganda Bureau at Nanchang supported the idea that Green GDP accounting was the foundation of, and a necessary precondition for, environmental protection. He argued that for the sake of 
Green GDP, short term interests had to be sacrificed and green growth had to be guaranteed (Li 2009).

These activities on the side of certain provincial and local governments were by far not representative of the overall attitude towards Green GDP accounting at the grass roots level. Many local administrators argued that "Green GDP did not comply with reality in China". They argued that China was still in the process of overcoming poverty which is why it could not afford not to go for an "economy first" strategy. They feared that Green GDP accounting would make their local economic growth look too bad (Wen 2015). According to reports from 2007, some local governments urged SEPA and NBS not to publish data obtained under the Green GDP project (Wang 2007). Three prominent antagonists were Ningixa 宁夏, Hebei 河北, and Shanxi 山西 (Li and Lang 2010, p. 52). They feared that the introduction of Green GDP accounting would have a negative effect on them attracting necessary investments. This kind of argument gained in prominence with the 2008 World Economic Crisis. Although the central government's strategy asked for investments in Green Economy, it did not mention Green GDP accounting in a situation where China was struggling with falling growth rates (Xinhuawang 2015).

In addition, local administrators are exposed to pressures coming from the grass roots. Local governments are highly dependent on tax income generated by industrial enterprises (Steinhardt and Jiang 2007; Tilt 2009). It is only through these taxes that they can afford to offer services and public goods to the local population. They generally wish to maximize the growth of local industry and commerce, both to fill their own coffers and to expand the employment base for the growing working-age population (Lieberthal 1995, p. 285). This is the reason why they have for a long time been able to count on gaining support from the local population despite the fact that additional companies often added to environmental degradation.

However, the growing discontent among the local people due to pollution cannot be ignored anymore by the government. Pollution has become one of the major causes of social unrest. Even though these protests have no organizational basis and the participants and reasons for protest vary enormously, they are now considered as a potential threat for social stability and thus for regime stability. As one article states: The Central government is now paying unprecedented attention to environmental issues (Xinhuanews 2015).

It was under these auspices that the idea of Green GDP resurfaced at the central level quite unexpectedly when the new Environmental Law was passed in 2014. The director of the policy department of the Ministry of Environmental Protection (MEP) Li Qingrui 李庆瑞 announced the re-launch of the Green GDP Project as Green GDP 2.0 explaining that the new law made the implementation of Green GDP accounting necessary. Starting from January 2015, local governments were held responsible for the environment in the area under their control. For that reason, a system had to be established which was able to calculate the resource potential of a certain region as the basis of a system of responsibility defined by certain aims which would be included into the cadre assessment system (Qie 2015). The reason for this announcement was a decision taken by the CCP leadership on March 24, 2015 asking for more efforts on behalf of establishing an ecological civilization (生 态文明). This together with the new Environmental Law initiated two years of 
intensive research on the development of Green GDP accounting methods worldwide and two additional years of pilot implementations. When Green GDP will eventually be implemented as the basis of assessing local governments in terms of the economy and the environment has not yet been decided and depends on the results of local pilot implementations and their analysis. (Huanjingbu 2015).

\section{Green GDP as the basis for the reform of the cadre assessment system}

The most important aspect of this relaunch is its relationship to the cadre assessment system. In the past, researchers inside and outside of China argued time and again that China was not lacking appropriate legislation for the protection of the environment. The biggest problem was the so called "implementation gap" which resulted from local governments refraining from implementing the laws as a consequence of their performance being exclusively measured by the economic growth they achieved year by year. This was not only true for local governments as such, but also for each and every cadre working at the local level. Their remuneration, office tenure, and higher appointments were contingent with the performance of their locality in terms of GDP growth (Whiting 2004, p. 111). As one cadre was compared with the other, and one region measured by the success of another region, this competition encouraged regional governments to prioritize high profit enterprises even if they contaminated the environment and violated environmental laws (Wen 2015).

However, in 2013, the organizational department of the CCP Central Committee promulgated the idea that the cadre evaluation system had to be reformed and aspects of environmental protection included into the system. This was part of the preparation for the 3rd plenary session of the 18th Central Committee which on its meeting at the end of 2013 decided on the introduction of a new responsibility system for cadres. The new system was supposed to force cadres into caring for “ecological civilization” (生态文明). The “Southern Daily” summarized the underlying idea by stating: "A government that does not attach importance to ecological civilization is an insane government; a leadership which does not attach importance to ecological civilization is a leadership which does not fulfill its duty; a company which does not attach importance to ecological civilization is a company without hope; and citizens who do not attach importance to ecological civilization are citizens without the kind of consciousness citizens of a modern civilization should be equipped with." (Nanfang 2017).

At the same time, the CCP Central Committee urgently asked specialists to design a quantitative system of measuring ecological damage (Xinhuawang 2015). It was clearly the CCP's intention to avoid resistance against the reform by making successes and failures quantitatively measurable. Without numbers as "hard facts" forming the basis of evaluation, it would have been too easy to argue that the system was "unscientific" and unfair. At the same time, the Ministry for Environmental Protection and the small group working on Green GDP in the ministry realized that with this new evaluation system time had come for a relaunch of a public debate on Green GDP. Finally, their resilience in continuing to work on the issue despite the 
media's loss of interest could show effect and the opportunity they had been waiting for had come.

Media reports for 2016 show that since the relaunch in 2014/2015 a myriad of activities has been initiated to mitigate the difficult technical problems of Green GDP accounting and to produce solutions which make the calculations more reliable and more convincible. In this context, the Department for Government at Huazhong University for Science and Technology produced a report on the Green GDP of Hubei during the years 2008 to 2014. This report was given a lot of attention as it "used an accounting system and methodology which could be considered in all of China as well as in the world at large as a good example of assessing Green development to propagate and emulate." (Zhongguo 2017). Media reports applauded to the publishing of the report with great fanfare by introducing it as based on a new "Chinese method" of calculation which was much more advanced than what had been suggested internationally in former times. "Everybody says the whole world needs China's wisdom, and the development in China needs the wisdom of think tanks". (Zhongguo 2017).

In the summer of 2017, Jiangsu province announced that it had already integrated environmental indicators into its cadre assessment system. Its "Indicator System for Green Development in Jiangsu Province” (江苏省绿色发展指标体系) put two indicators related to the environment in top priority positions. "The use of resources" and "the quality of the environment" are from now on important aspects of their cadre assessment system. These indicators are, according to the understanding of the authors of this system, "scientific" much in contrast to the lack of scientific understanding and attention which had prevailed the situation earlier and had caused the environmental problem the province is now confronted with. Interestingly, the report also says that "participation" is an important indicator. Opinion polls are being conducted in order to find out the degree of satisfaction among the population. This is how the province wants to overcome current problems by "pulling the ox by its nose" (Lizhiwang 2017).

\section{Green GDP: a practical solution?}

In this sense, the re-launching of the Green GDP project is a major break-through in China's environmental policies. It is a practical solution which will help to overcome the implementation gap by making local cadres accountable for what is happening in terms of the environment locally. By nailing the issue down to their personal career interests, cadres will most probably swiftly adapt to the new requirements and find ways to cope with them; and by convincing them that the indicators provide for an objective assessment of their contributions they will most probably accept this newly introduced responsibility system the way they accepted the one in place before. Thus the government can expect immediate compliance rather than an enthusiastic response with cadres working exclusively on economic growth not expected to change into environmental activists instantaneously (She 2017). 
Another reason to anticipate that Green GDP accounting will eventually get rooted in Chinese politics is the path dependence of the idea. As the formerly used indicator of GDP growth, Green GDP relies on the so called objectivity of data and numbers and thus provides "hard" indicators for the assessment. In addition, the assessment procedure relies on a philosophy which identifies human activity as the main, if not the only solution. When China was still struggling with poverty, people were made to believe that their individual effort could change their fate. In the same vain, the assessment system which puts local cadres at the very center of responsibility for the environment is based on the philosophy that man-made mistakes can be overcome by human action. The circle closes by communicating that human action based on data is scientific and thus compliant with the necessities of a world of growing complexity. The exclusive focus on economic growth is labelled as "blind", whereas the new focus on Green GDP is regarded as "scientific". Last but not least, the idea of switching from GDP-ism to Green GDP has yet another appeal: China can overcome its bad image of uncontrolled pollution by assuming an avant-garde position by way of introducing Green GDP accounting.

The technical problems of coming to a methodologically sound calculation procedure are not mentioned prominently in recent publications. While NBS had ranked this problem highly back in 2007 when the first attempt to introduce Green GDP accounting came to a sudden halt, recently the political considerations formerly forwarded by SEPA and now by the Ministry of Environmental Protection have gained the upper hand. The most important reason for this change in attitude is the daily aggravating situation of the environment and growing societal unrest all over China. As the documentary "The Dome" shows (Chai 2015), fears about the health consequences of pollution are wide spread among the population at large, but especially among the affluent middle class which the CCP has been trying to accommodate by integrating it into its economic growth only policy since the late 1980s. This middle class counts among the most prominent beneficiaries of the CCP's turn towards reform and opening. While it clearly benefited from the CCP's policy of economic growth, it now turns around and sees itself as a victim of this policy. The long held friendship between the CCP and the middle class is in danger. This is why government reactions to middle class protests about the environment tend to be much more responsive in comparison to demands raised by the rural population (Liu et al. 2008). Against this backdrop, symbolic actions are more important than technical solutions. The turn away from GDP-ism of Green GDP accounting is convincing by itself despite the fact that methodological problems are still under scrutiny. This time the Ministry of Environmental Protection won the battle when re-launching the idea of Green GDP because it seized the opportunity of the PRC leadership desperately in need of an appealing policy convincing the Chinese middle class that the government was taking action.

As a consequence of the same logic, the responsibility for the environment has been shifted down to the local cadres. With the new environmental law and the responsibility system accompanying it, the central government can make clear more easily than in the past that environmental problems have to be taken care of locally. Thus when protests arise, they will stay local and at low levels of hierarchy, while criticism voiced both in China and internationally can be directed against local 
actors rather than the central leadership. This is how the new responsibility system helps keeping environmental protests from developing into a threat for the stability of the Chinese state and its one-party system.

However, there are also voices which raise doubts about the practicality of the system. They argue that the choice of indicators makes Green GDP calculation still a highly "subjective" undertaking. In addition, because there is no consensus on the calculation procedure, the many different ministries and agencies involved in the implementation of the new policy will find all kinds of reasons to quarrel with each other (Xinhuawang 2015).

To sum up, a very special political and social constellation has created the opportunity in the PRC to opt for implementing a system of Green GDP accounting. The PRC has the unprecedented chance to act as the forerunner of a new GDP accounting system which after overcoming its technical problems might eventually set the standards worldwide. This system will most likely have an impact on the environmental situation in China as it helps to overcome the implementation gap that so far has been one of the most prominent reasons why the environmental crisis has been aggravating despite undeniable efforts at the central level of the political system. However, the eventual introduction of a Green GDP accounting system is not a sign of a fundamental change in either policy or attitude on the side of the decision makers involved. It is exactly because the Green GDP accounting system is not a radical break away from former practices that it is expected to be implemented first in a couple of provinces and later on nationwide. The above discussed path dependency of the system helps to find support for the implementation of this new policy despite the well-known technical problems of Green GDP accounting.

\section{Green GDP and big data}

In order to foster confidence in its capability to work with reliable data, the Ministry for Environmental Protection announced that it would use satellite observation and other novel techniques to establish a big data data base for the protection of the environment (Chinanews 2015). Thus, the ministry seems to cover up the existing technical problems of Green GDP accounting and replace the design of a convincing methodology by big data mining and accompanying control mechanisms. But $\mathrm{Hu}$ Tao 胡涛, the director of the Academic Advisory Board of the State Environmental and Economic Policy Research Center (国家环境与经济政策研究中心学术委员 会) does not seem convinced of the reliability of environment related data. Instead he warns against "fake data": "Since the traditional GDP data could be made up, who would dare to guarantee that Green GDP is not distorted unless we make a fundamental turn around? The uncertainty of its accounting procedure might open up even more space for distortion." (Wen 2015). The reason is easy to understand: In the past, GDP data were used to assess cadres' contribution to GDP growth at the local level; in the future, Green GDP data will be used to assess cadres' compliance with environmental laws and policies. As this assessment was and will be related to their personal career development, there is reason to believe that Green GDP data 
will be distorted at least by some people the way production data were distorted in the past (Wallace 2016).

In the PRC, we are confronted with the phenomenon that state and society are equally obsessed with numbers. Much in contrast to the Maoist past when "doing things with words" (Schoenhals 1992) dominated the political process, with Deng Xiaoping re-launching the slogan that "practice was the only criterion of truth" (实 践是检验真理的唯一的标准) the idea was accepted by society that numbers were the most reliable reflection of action (i.e. practice) and therefore true. Yet inside and outside China everybody who wants to know can know that numbers are more often than not made up, manipulated and used for political ends (Liu 2009, pp. 11; 1518). The use of numbers has already entered the political power play between state and society as well as between the center and lower echelons of the administration. As everybody participates in this game, everybody knows.

This way of manipulating numbers was a major problem during the Great Leap Forward when the central government did not stop asking for higher productivity in agriculture. The local cadres reacted by reporting ever growing numbers on the basis of which the center raised the quota of grain contributions. This is how the Great Famine (1959-1961) came about causing the death of tens of millions with estimates ranging between 15 und 45 million people. Nobody believed the numbers when starvation was first reported to the central government. Consequently, Mao and his entourage took the reports on starvation for sabotage of the peasants and refrained from action. Even when center level politicians were sent to the countryside and reported back that starvation was indeed a widespread phenomenon, Mao could deny the truth of their findings and label them as counterrevolutionaries (Wemheuer 2014).

Against this terrifying experience of the past, one would expect that the more recent return to "doing things with numbers" was reflective of previous mistakes and in this sense more cautious. And, indeed, in its most recent variety it is. With the Ministry of Environmental Protection announcing to use satellites for monitoring the environment, it gives a signal that it believes to be able to collect data independently of local collaboration. This new access to local data would change the relationship between central and local governments in China dramatically. So far, the difficulty of controlling the information flow from the bottom to the top of the administrative system was part of the above mentioned implementation gap and one reason for "local autonomy" beyond the control of the center. However, the more data are centralized and monopolized as the new SEPA policy suggests, the less they can be contested. Under such conditions, central government institutions monopolizing data might argue that their data must be true as they were gathered by technology independent of human intervention. They will not disclose that the algorithms by which the data were gathered and selected are man-made. Thus while people will continue to doubt the truth of certain numbers based on their historical experience, monopolization of data will disempower them to the point of no return.

In addition to pointing to the possibility of the Green GDP project to degenerate into a "utopian movement of playing green numbers" (Wen 2015) or develop into a project of disempowerment the idea of big data as a basis of Green GDP accounting implies yet another danger which needs to be taken into account. The Xi Jinping 习 
金平 leadership announced its overall top-down big data policy in 2015 and has invested heavily into introducing the use of big data to its governance repertoire (Zeng 2016). This has economic as well as political implications. Big data can provide and process the kind of information that the state needs in order to reestablish itself as the central planner and agent of economic development. In addition, projects like "Healthy China 2030" and the so called "Social Credit System" which "aims to nudge citizens and companies into rule-abiding behavior by evaluating data ranging from payment morale or compliance with traffic rules and environmental regulations to opinions voiced in online chatrooms" (Heilmann 2017) also strongly rely on big data. "The prospect of reaching a goal that has historically eluded Communist rulers, the perfection of centralised control, propels the CCP's intense and long-term commitment to digitisation", says Sebastian Heilmann in a recent Financial Times article (Heilmann 2017).

Zeng lists quite a number of domains in which big data can help intensifying control. However, he also mentions the possibility that big data might generate a new form of inner-elite political struggle. The more the elite knows by help of big data, the more this knowledge can be used in inter-factional struggle (Zeng 2016, pp. 14581461). Alas, the example from recent inner-elite conflicts which he refers to are more of a conventional kind with members of the Chinese elite leaking secret information over social media after leaving the country. The leaking of information during the process of power transfer before the 18th national congress with the New York Times acting as platform for the publication of corruption details had nothing to do with big data. This incident and others like the recent social media offensive by Guo Wengui 郭 文贵 (The Guardian 2017) with new elite internal information conveyed virtually on a daily basis only shows that the regime in China is having a loyalty and coherence problem. It has not yet reached the point of playing big data in political struggles. However, with Xi Jinping going for a centralization of data, he takes the risk of hacker attacks with enormous consequences no matter where they come from.

On the long list of possible areas of control via big data, Zeng does not mention environmental issues. The possibility of radical rather than incremental policies necessitated by an ever aggravating environmental crisis and generating control mechanisms leading to environmental authoritarianism is an under-researched field. While researchers discuss the prospects of democracy in the context of climate change, they tend to overlook the possibility that both the technical solutions for sustainability as well as the degrowth alternative might come with coercive measures. Societal forces either struggling against new technologies or sticking to consumer behaviour incompatible with a degrowth policy can easily turn into objects of supression for the good of society as a whole and the environment as such (Karlsson 2013). Crutzen gives this kind of mechanism a more positive appeal by referring to it as "large scale geoengineering project" (Crutzen 2002, p. 23) and by consciously or unconsciously delinking it from the nation state. But as the environmental situation in China definitely asks for immediate action, hardly anybody dares to raise the issue of possible implications for the polity. Julie Sze seems to be a rare exception when she describes in her book about Chinese environmental fantasies and fears some of these issues in the context of the Shanghai World Exhibition as a top down approach to change Shanghai into a green city (Sze 2015). 
Indeed, Green GDP might not only help to solve the problem of implementation gap between the central and the local governments in the area of environmental policies. It is also a project which needs big data as its basis and therefore more monitoring, and more control. Green GDP accounting not only measures the use of resources and the degree of environmental depletion, it also needs to monitor the environmental compliance of companies and individuals. Especially in countries with big populations like China, individuals can make a difference. That is why Green GDP accounting needs to include data on how individuals use rare resources such as water and energy, treat their waste and take care of their health by eating what they are supposed to eat, sticking to their daily sport activities and refraining from every kind of "guilty pleasure" such as drinking and smoking. The "smart city" ideas some planners develop in China include monitoring every citizen in his or her private surroundings so as to support environmentally friendly behaviour $24 \mathrm{~h}$ 7 days a week. This kind of monitoring can help governments to be more responsive to the needs of citizens, but it will at the same time make citizens controllable by the government and unable to survive without the government. In this give and take between state and society, the state will become stronger, and society weaker. For the individual this means that the difference between private and public will no longer exist, and mainstreaming will no longer be avoidable. Putting this unfortunate assessment into the context of the Anthropocene, we can only come to the conclusion, that mankind, by positioning itself at the very centre of the universe, not only has embarked on a path towards destroying its natural habitat, but also towards fundamentally changing the kind of lifestyle which so far has left room for individualism and disobedience. "If China manages to harness Big Data technologies to build a top-down, yet responsive system of governance that turns out to be politically effective, economically productive and socially stable, it has the potential to become a global model.", says Sebastian Heilmann. This will be especially true if China manages to overcome its ecological crisis and re-position itself from being the No 1 perpetrator in terms of pollution to the No 1 problem solver with the help of Green GDP accounting.

\section{Conclusion: China, Green GDP accounting and the Anthropocene}

My discussion on China, Green GDP and the Anthropocene has generated a few results which might be of some interest for the general discussion on the Anthropocene. First and foremost, we have to realize that in China the distance between detecting the problem and solving the problem is by no means smaller than anywhere else in the world. Religions in China have not generated ideas about the relationship between man and nature which could inspire our search for solutions worldwide more than other belief systems around the world. There are artists and writers trying to imagine a future for life in the Anthropocene, but as my reading of Zhao Defa's novel "The Anthropocene" has shown, their intuition has not yet generated a solution either. The idea of Green GDP accounting pursued with more intensity in China than in other parts of the world is a possible piece meal solution with quite some expectable effect, however, if experts in the PRC eventually reach 
their aim of defining the standards for GDP accounting non-Chinese will have to turn their perspective on things around: So far many observers outside China believe that by importing Western technology, people in China will sooner or later start thinking the way people in democratic societies outside China think. If this is truewhich to my mind is a contestable assumption-, then we will have to turn around and acknowledge that influence can also take place in the opposite direction. By adapting the Green GDP model created in China, we will eventually learn to emulate the rationale behind it. This rationale not only includes the idea of taking the environmental costs of economic growth into account; it also contains ideas of authoritarian governance reinforced by the urgency of the daily aggravating environmental crisis. Rather than giving this kind of governance the appealing name "large scale geo-engineering projects" (Crutzen) we should openly confront this turn around and its possible side effects.

Finally, looking at the discussion on the Anthropocene, we realize when looking at it from a distance that the catchword Anthropocene is as political as other catchwords like sustainability, and resilience, only to name a few. The term "Anthropocene" itself is still under debate, and discussions on the question of how to periodize the geochronology show that different suggestions rely more on weltanschauung than on scientific data and research related considerations. Those who go for radical solutions should keep in mind that China was verberated by revolution for more than 100 years before the ruling elite took the decision to revert to a policy of reform and opening. The blood toll which these years of revolutionary struggle took has been enormous. The conclusion one can draw from this experience can be summarized in one sentence: to accelerate the cure can prolong the disease!

In comparison, Green GDP accounting can bring about incremental improvement of the situation. Although-as shown above-Green GDP accounting is still confronted with a myriad of problems, some of the described issues are generated by its path dependency. Doing things with numbers is the problem and the solution. Paradoxically, it is exactly this path dependency which makes Green GDP likely to be eventually implemented in China in a way which will bring about positive effects for China and the world at large.

Acknowledgements Open access funding provided by University of Vienna.

Open Access This article is distributed under the terms of the Creative Commons Attribution 4.0 International License (http://creativecommons.org/licenses/by/4.0/), which permits unrestricted use, distribution, and reproduction in any medium, provided you give appropriate credit to the original author(s) and the source, provide a link to the Creative Commons license, and indicate if changes were made.

\section{References}

Alfsen, K. H., J.L. Hass, T. Hu, and Y. Wu. 2006. International Experiences with “Green GDP”. https:// www.ssb.no/en/natur-og-miljo/artikler-og-publikasjoner/international-experiences-with-green-gdp. Accessed 23 Oct 2017.

Bostic, H., and M. Howey. 2017. To Address the Anthropocene, Engage the Liberal Arts. Anthropocene 18: $105-110$. 
Chai, Jing 柴静. 2015. Under the Dome. Air Pollution in China. https://www.youtube.com/watch?v= V5bHb3ljjbc. Accessed 23 Oct 2017.

Chang Jie 常婕. 2009. 湖北建立绿色 GDP 核算体系的策略研究. 理论界 1:78-79.

Chin, A., L. Gillson, S.M. Quiring, D.R. Nelson, M.P. Taylor, V. Vanacker, and D. Lovegrove. 2016. An Evolving Anthropocene for Science and Society. Anthropocene 13: 1-3.

China Daily. 2004. China Plans to Set Up Green GDP System in 3-5 years. http://www.chinadaily.com. cn/english/doc/2004-03/12/content_314332.htm. Accessed 23 Oct 2017.

China Online. 2007. 谢伏瞻: 目前尚无法进行绿色 GDP核算. http://www.china.com.cn/news/2007-07/ 12/content_8515731.htm. Accessed 23 Oct 2017.

Chinanews. 2015. 环保部重启绿色 GDP 研究 当年遭一些地方及部门反对. http://www.chinanews. com/gn/2015/03-31/7170958.shtml. Accessed 23 Oct 2017.

Crutzen, P.J. 2002. Geology of Mankind. Nature 45: 23. http://www.unife.it/scienze/lm.ecologia/ Insegnamenti/management-degli-ecosistemi/materiale-didattico/Crutzen\%202002.pdf. Accessed 23 Oct 2017.

Development Plan. 2005. 地球科学 “十一五” 发展战略. www.nsfc.gov.cn/upload/2005-12.../ 20051215114521503.doc. Accessed 23 Oct 2017.

Fenghuang Zixun. 2016. http://news.ifeng.com/a/20160806/49729476_0.shtml. Accessed 23 Oct 2017.

$\mathrm{Fu}$, Keyou 付克友. 2009. 让神农架绿色 GDP 变成真金白银. http://news.sina.com.cn/pl/2009-06-04/ 133417950916.shtml. Accessed 23 Oct 2017.

Ge, Fei 格非. 2012. 江南三部曲. Shanghai: Shanghai Wenyi Chubanshe.

Gebhardt, H. 2016. Das „Anthropozän“- zur Konjunktur eines Begriffs. HDJBO. https://doi.org/10. 17885/heiup.hdjbo.23557.

Heilmann, S. 2017. Big Data Reshapes China's Approach to Governance. Financial Times, 29 Sept 2017. https://www.ft.com/content/43170fd2-a46d-11e7-b797-b61809486fe2. Accessed 23 Oct 2017.

$\mathrm{Hu}$, Jintao 胡锦涛. 2005. 在中央人口资源环境工作座谈会上的讲话 (2004 年 3 月 10 日). 十六大以来 重要文献选编(上), 850. Beijing: Zhongyang Wenxian Chubanshe.

Huanjingbu. 2015. 环境保护部重启绿色 GDP 研究. http://www.ccchina.gov.cn/Detail.aspx?newsId= 51776\&amp\%3BTId=57. Accessed 23 Oct 2017.

Jahn, T., D. Hummel, and E. Schramm. 2015. Nachhaltige Wissenschaft im Anthropozän. GAIA 24 (2): 92-95.

Karlsson, R. 2013. Ambivalence, Irony, and Democracy in the Anthropocene. Futures 46: 1-9.

Lelyveld, M. 2006. China's "Green GDP” Estimate Disputed. http://www.pacificenvironment.org/article. php?id=1981. Accessed 23 Oct 2017.

Li, V., and G. Lang. 2010. China's "Green GDP" Experiment and the Struggle for Ecological Modernization. Journal of Contemporary Asia 40 (1): 44-62.

Li, Wei 李蔚. 2009. 南昌 “差异化考核” 背后的绿色 GDP. http://news.163.com/09/0609/09/ 5BC06DLO00011SM9.html. Accessed 23 Oct 2017.

Lizhiwang. 2017. 江苏将绿色 GDP 正式纳入干部考核. http://news.jstv.com/a/20170816/ 1502837694871.shtml. Accessed 23 Oct 2017.

Lieberthal, K. 1995. Governing China: From Revolution through Reform. New York: Norton.

Liu Dongsheng 刘东生. 2004. 开展 “人类世” 环境研究, 做新时代地学的开拓者 - 纪念黄汲清先生 的地学创新精神. Quaternary Science 24: 4. https://doi.org/10.3321/j.issn:1001-7410.2004.04.001.

Liu Xiaoqing 刘小青, Ren Bingqiang 任丙强. 2008. “怒江” 建坝决策中的公众环境政治参与个案研 究. Journal of Beijing University of Aeronautics and Astronautics (Social Sciences Edition) 21: 3235.

Liu, Xin. 2009. The Mirage of China: Anti-humanism, Narcissism, and Corporeality of the Contemporary World. New York: Berghahn.

Liu, Xue 刘 学, Zheng, Junwei 郑军卫, Yang, Zongxi 杨宗喜. 2017. 人类世的由来及其研究新进展. http://www.drc.cgs.gov.cn/maga/dzdcdt/201704/t20170419_427517.html. Accessed 23 Oct 2017.

Nanfang Ribao. 2017. 用绿色 GDP 唤醒对生态文明的重视. http://wap.longquanzs.org/ryzr/hjbh/ 61851.htm. Accessed 23 Oct 2017.

Ni, Xiaoqiang. 2004. The Way to Green GDP. http://www.china.org.cn/english/2004/Jun/96974.htm. Accessed 23 Oct 2017.

Pye, M., Ch. Kleine, and M. Dech. 1997. Ökologie und Religionen. Eine religionswissenschaftliche Darstellung. Marburg Journal of Religion 2(1). www.uni-marburg.de/fb03/ivk/mjr/pdfs/1997/ articles/pye-kleine-dech1997.pdf. Accessed 23 Oct 2017.

Qie Jianrong 郄建荣. 2015. 绿色 GDP 研究 9 年后重启. http://news.xinhuanet.com/legal/2015-03/31/c_ 127639484.htm. Accessed 23 Oct 2017. 
Qiu, Jane. 2007. China's Green Accounting System on Shaky Ground. Nature 448: 518-519. https:// www.nature.com/nature/journal/v448/n7153/full/448518a.html. Accessed 23 Oct 2017.

Schoenhals, M. 1992. Doing Things with Words. Berkeley: Institute of East Asian Studies.

She, Zongming 余宗明. 2017. 珍视绿色 GDP 绩效评估的中国版 “方法论” . http://focus.cnhubei. com/original/201706/t3851614.shtml. Accessed 23 Oct 2017.

Snyder, S. 2006. Chinese Traditions and Ecology. Survey article. Worldviews 10 (1): 100-134.

Steinhardt, C.H., and Y. Jiang. 2007. The Politics of China's "Green GDP”. China Aktuell 5: 25-39.

Sze, Julie. 2015. Fantasy Islands: Chinese Dreams and Ecological Fears in an Age of Climate Crisis. Oakland: University of California Press.

The Guardian. 2017. Guo Wengui, the Maverick Chinese Billionaire Who Threatens to Crash Xi's party. https://www.theguardian.com/world/2017/oct/16/guo-wengui-the-maverick-chinese-billionairewho-threatens-to-crash-xis-party. Accessed 23 Oct 2017.

Tilt, B. 2009. The Struggle for Sustainability in Rural China: Environmental Values and Civil Society. New York: Columbia University Press.

Tuan, Yi-fu. 1968. Discrepancies Between Environmental Attitude and Behavior: Examples from Europe and China. The Canadian Geographer 12: 176-190.

Wang Haiping 王海平. 2007. 绿色 GDP 核算可使经济增长转负. http://business.sohu.com/20070619/ n250648380.shtml. Accessed 23 Oct 2017.

Wang, J.N., Y.T. Lu, and D. Cao. 2004. The Updated Progress and Perspective of Environmental Economics in China. http://www.caep.org.cn/english/paper/The-Updated-Progress-ofEnvironmental-Economics-in-China-2004.pdf. Accessed 23 Oct 2017.

Wang, Yichao 王以超. 2007. “绿色 GDP” 形进实远. http://china.caixin.com/2007-03-01/100357967. html. Accessed 23 Oct 2017.

Wallace, J. 2016. Juking the Stats? Authoritarian Information Problems in China. British Journal of Political Science 46 (1): 11-29.

Watts, A. 1958. Nature, Man and Woman. New York: Pantheon.

Wemheuer, F. 2014. Famine Politics in Maoist China and the Soviet Union. New Haven, London: Yale UP.

Wen Jia 闻嘉. 2015. 今日话题: 绿色 GDP 真有那么美好吗? http://view.news.qq.com/a/20150415/ 018034.htm. Accessed 23 Oct 2017.

Whiting, S. 2004. The Cadre Evaluation System at the Grassroots. In Holding China Together, ed. B.J. Naughton, 101-119. Cambridge: Cambridge UP.

World Bank. 2007. Statement from World Bank China Director on "Cost of Pollution in China Report". http://www.worldbank.org/en/news/press-release/2007/07/11/statement-world-bank-china-countrydirector-cost-pollution-china-report. Accessed 23 Oct 2017.

Wu, Jianghai 吴江海. 2009. 黄山市正式确立 “绿色 GDP” 的工作指导思想. http://www.eedu.org.cn/ news/region/huadong/ah/200901/32647.html. Accessed 23 Oct 2017.

Xinhuanews. 2015. 环保部重启绿色 GDP 研究当年遭一些地方及部门反对. http://www.chinanews. com/gn/2015/03-31/7170958.shtml. Accessed 23 Oct 2017.

Xinhuawang. 2015. 绿色 GDP: 从中断的地方重新出发 http://news.xinhuanet.com/fortune/2015-04/ 02/c_127650222.htm. Accessed 23 Oct 2017.

Yu, Fang, Jiang, Hongqiang, Cao, Dong, Wang, Jinnan, Ge, Caizhong. 2006. Integrated Environmental and Economic Accounting in China: Proposed Framework and Preliminary Findings. http://unstats. un.org/unsd/envaccounting/londongroup/meeting10/LG10_25a.pdf. Accessed 23 Oct 2017.

Zeng, Jinghan. 2016. China's Date with Big Data: Will it Strengthen or Threaten Authoritarian Rule? International Affairs 92 (6): 1443-1462.

Zhao, Defa 赵德发. 2016. 人类世. Wuhan: Changjiang Wenyi Chubanshe.

Zhongguo Qingnianwang. 2017. 中国绿色 GDP 绩效评估报告 (2017年湖北卷)》在京发布. http:// news.china.com/news100/11038989/20170815/31093867.html. Accessed 23 Oct 2017.

Riemenschnitter, Andrea (Forthcoming). Ge Fei and His South of Yangtse Trilogy. In Routledge Handbook of Modern Chinese Literature. Taylor \& Francis. 